\title{
Experiential Graduate Education: An Experiment in Transformative Learning
}

\author{
Marilyn Laiken, Ontario Institute for Studies in Education \\ of the University of Toronto
}

\section{AbSTRACT}

Five years of teaching a graduate course in organizational learning have convinced the author that the course has a transformative impact on her mature adult students. The article examines the nature of this form of experiential education in the light of transformative learning theory and learning organization concepts. Using the course as a case example, the author offers a number of specific approaches to: developing a constructive learning environment; enhancing team learning; surfacing and discussing assumptions; supporting systems thinking; and personal mastery. Finally, the author examines the role of the instructor as a facilitator of transformative learning. The objectives are to help adult educators reflect on one kind of environment that seems to have a transformative impact and to explore how to continue to successfully design such experiences for and with adult students.
RÉSUMÉ

Après cinq ans d'enseignement d'un cours du second cycle universitaire, l'auteur est convaincue que ce même cours a un impact transformatif sur ses étudiants adultes. Elle examine la nature de cette forme d'apprentissage expérentiel à la lumière d'une théorie d'apprentissage transformatif et d'un apprentissage de concepts d'organisation. En utilisant ce cours comme exemple de cas, l'auteur offre un nombre d'approches spécifiques à: un développement de milieu d'apprent issage constructif; une amélioration d'apprentissage d'équipe; une présentation et une discussion d'hypthèses; l'appui d'un raisonnement complet; une maîtrise personnelle. Finalement, l'auteur examine le rôle de l'instructeur comme facilitateur de l'apprentissage transformatif. Ses deux objectifs sont $\mathrm{d}^{\prime}$ amener les instructeurs à une réflexion sur un milieu semblant avoir un impact transformatif sur ses apprenants, et deuxièmement, d'explorer la possibilité d'une élaboration continuelle de telles expériences transformatives pour et avec des étudiants adultes. 
I still suffer from perceptual vertigo. My point of view shifted continuously ... I am not the same person who started the journey.

(Student, course 1130 final paper)

\section{INTRODUCTION}

For the past five years I have taught graduate courses in the Adult Education Department at the Ontario Institute for Studies in Education in Toronto. One course in particular has captured the attention of many of my colleagues and students. We affectionately refer to it as "1130," although its formal title is "A Participant-Directed Seminar: Learning in Organizations."

The course provides an opportunity for students to create their own learning organization, with my help as the instructor, in a facilitative role. The key concepts of systems thinking, personal mastery, examining mental models, team development, and building a shared vision (Senge, 1990) provide a theoretical framework through which group members explore their learning experience. The group is helped to develop as a learning community through a residential weekend that combines an "outward bound" approach with sharing personal goals and resources. Participants end their weekend by planning for their three-month future as an "organization" with an action-learning orientation.

I have chosen to write about this course because it is regularly described by my mature adult students as "the best learning experience I've ever had" or "a course which has been a series of 'aha's and inspirational moments.'" In the evaluations at course end, students consistently write comments such as these:

...we were truly empowered to make this course as great as we wanted; learning was phenomenal at a personal and group level.

I feel like I have expanded my thinking and improved the quality of my ways of processing information, ideas and concepts. It has also had a tremendous impact on clarifying my vision and values, resulting in some significant changes both personally and in my business.

I suggest such comments indicate that participants have experienced what is described by many theorists as "transformative learning" (Brookfield, 1987; Jarvis, 1992; Mezirow, 1991). This concept is defined by Patricia Cranton in Understanding and Promoting Transformative Learning as "the development of revised assumptions, premises, ways of interpreting 
experience, or perspectives on the world by means of critical selfreflection"(1994, p. xii).

Creating a transformative learning environment involves a great deal more than transmitting a body of content, or even helping learners to attain new skills. Educational theorists such as Cross (1992), Knowles (1984), and Mezirow (1991) differentiate between "subject-oriented," "consumeroriented," and "emancipatory" or "transformative" learning. Subjectoriented learning involves the learner in acquiring new knowledge and skills. In consumer-oriented learning, the educator is attempting to directly meet the expressed needs of the learners. Although transformative or emancipatory learning may include the above, learners are also encouraged to develop their reflective judgement, in order to surface assumptions and potentially to revise their established world views. Cranton (1994) says: "If we view education as the means by which individuals and societies are shaped and changed, fostering emancipatory learning is the central goal of adult education" (p. 19). I would agree.

Many adult learners and educators who have experienced transformative learning also agree that it can be a difficult and often painful process. As one of my mature students has said, "It wasn't a balloon ride, but my view has certainly been altered." Cranton describes this type of learning as "probably the most complex and difficult experience from the learner's point of view, and the most challenging for the educator" (1994, p. 21).

How, then, can adult educators meet this challenge in a way that both derives the benefits of transformative learning and avoids some of the obstacles? The objective of the remainder of this paper is to analyze the design and implementation of course 1130, to better understand not only what kind of learning environment has a transformative impact, but also how we, as adult educators, might continue to successfully design such experiences for and with our adult students.

As a framework for this exploration, I have used Peter Senge's five disciplines for building a learning organization (1990). As previously mentioned, these include: creating a shared vision; team learning; examining mental models; personal mastery; and systems thinking. The paper is organized around these ideas because they comprise a basic theoretical structure for course 1130. Beyond such concepts, the remainder of the course content and most of its process are decided by the participants themselves to reflect individual and, ultimately, group learning needs.

Briefly, the general design of the course involves opening sessions (including the retreat weekend) that focus on introducing the learning 
organization concepts, developing a vision, sharing resources, deciding on course content, and establishing learning teams. The body of the course is mainly comprised of learning-team activities inside and outside of class, including a "learning event" conducted by each team for the remainder of the group, focusing on content chosen by the class as a whole. Interspersed between these events are reflective sessions that help each team share their learning process with the class and relate it to the learning organization concepts that have been introduced by the instructor. The course ends with group members evaluating their development as a learning organization, using the initial vision to help them reflect on the problems and opportunities they have encountered. Thus, in a truly experientially designed format, learners are helped to derive their learning from their lived experience-both from the process of the course itself and through the application of resulting insights to their lives at work. The following section explores in more detail each of the course components, combining descriptive data with an analysis of the participants' experiences that is supported by quotations from student papers and correspondence.

\section{Developing a Constructive Learning EnVIRONMENT:}

\section{CREATING A SHARED Vision}

Adult education theory has long acknowledged the importance of the emotional aspects of learning. Feelings such as self-doubt, concerns about "fitting in," and anxiety about having less (or more) to offer than others often accompany adult learners into the classroom-frequently as a result of past experiences where humiliation and frustration have dominated the learning environment. A new student to our program reflected in her final paper, on her feelings as she entered the course:

... little did I know what would be in store for me over the next three months. A slow start with a few bumps of self-doubt. Will I fit in? Will others share my interests or think them frivolous or unimportant? Do I have anything to offer here? How do I balance sharing my experience ... with a need not to be perceived as a "know-it-all?" Can I struggle through another course, another learning experience? Do I really want to do this now? Have I made the right choice?

The challenge then, right from the start of the program, is to help the learner acknowledge such discomfort and begin to use it as a basis for learning. It is essential to establish an environment that supports what I 
would call "optimal anxiety," where the learner is stimulated sufficiently to be open to learning, but not so anxious that she or he feels immobilized. Cranton (1994) describes such an environment as including three aspects: "trigger events" that stimulate critical reflection; a process that helps people become aware of and begin to question basic assumptions; and ongoing support and feedback from others.

The initial series of "trigger events" in course 1130 is provided by a residential experience. It includes negotiating a team climb through cliffs and caves; sharing personal learning goals ("gets") and resources ("gives"); envisioning the group's ideal learning organization; and then, using this vision as a target, planning for the remainder of the course. One student, reflecting on her experience in publicly announcing the personal resources she brought to the course, said:

As I reread the "gives" near the end of the course, I realized how shallow mine seemed. I had focused on what I had done in the past, rather than on what I could do. A mental model was uncovered. When asked to contribute, I tend to offer what I do, rather than who I am.

This same student also shared how her reflection and learning have had an impact on her ongoing work experience.

Understanding how I had initially contributed the "what" rather than the "who" to the group affected how I would like to act in my job. I have already started moving from a framework of "Here's what I can do" to a [consulting model which asks]: "What are your issues, and how can I help you address them?" I offer the whole me, rather than a shopping list of things I can do.

Developing a shared vision for the future we wish to create as a class is one of the factors in establishing an environment that supports this kind of learning. An organizational vision has several objectives: to align values, goals, and action; to create a shared framework for decision making and problem solving; to inject a new level of synergy and creativity into day-today functioning; and to engage the commitment and unique resources of each individual member. It is a guide to action, and, as such, it helps to create the culture and environment within which we do our work.

In course 1130 we create our vision in response to the question, "What would our 'learning organization' look like if it were the best it could be?" After pictorially representing her or his response to this question, each member shares it with five or six others in a small-group dialogue. Each 
group then decides on the key components of the visions discussed and finds a creative way to present these to the rest of the class. Through the use of skits, songs, poetry, collage, drawings, etc., we plumb the depths of participants' creativity, as they articulate their dreams for an ideal learning experience. The combination of components from each group's presentation becomes the vision for the class. It is produced as a wall chart, as well as typed and copied for everyone, as the start-up for the visioning process.

However, this is just a start. During the following three months the group works continuously on the vision, through a process of defining behavioural indicators for each component, comparing the reality of members' behaviour in class and in their work teams with these indicators, and problem solving to close the gaps between the vision and the reality whenever they arise. In this way we constantly monitor our actions to keep them consistent with the supportive, challenging, respectful environment that class members have envisioned as their ideal.

\section{TEAM LEARNING}

A second trigger event in course 1130 is the formation of learning teams. These teams evolve from the identification of specific areas of content about which participants wish to learn more. Through the use of a nominal group technique (Galbraith, 1990), the class identifies a number of areas of general interest, and then members vote individually on those that are most important to them in this course. The results indicate the whole group's priorities, which are then refined into topic areas around which class members group to form teams.

The task of each team is to plan and facilitate a two-hour "teachinglearning experience" for the remainder of the group. The specific goals for these events are based on the needs assessment that each team conducts with the rest of the class. Members are encouraged to view their event not as a "performance" or a "presentation," but as a learning opportunity for all of us, and especially for the facilitating team. In order to support this notion, there is no grade attached to the event itself. However, there are several opportunities for feedback and reflection on learnings-initially, immediately following each event, and then again one week later, when team members have had a chance to read written comments from every other class member. In this manner, a large portion of the course content is defined by the learners in a "consumer-oriented" approach. Nevertheless, the focus of learning becomes transformative, as learners are encouraged to 
constantly reflect on their own process as individuals, as a learning team, and as an evolving learning organization.

From the start, the team's formation and development are opportunities for learning. Fairly early in the group's life, learners are asked to make their own decisions about how to form their teaching-learning teams. They are encouraged to "shop around" and make personal decisions based on their individual learning needs. The challenge of choosing and being chosen (or rejected) by others is not lost on these students, as they are immediately confronted with historical fears, doubts, feelings of inadequacy, and issues of self-esteem. They are also challenged to be crystal clear about their own needs-both with themselves and with others-and to be unafraid of representing their strengths and resources, as well as their needs, in the negotiation process.

One student described her experience during the team formation period as "chaotic."

Chaos ensued as small teams formed and reformed to focus on the identified interest areas. Our unconscious incompetence resulted in unfocused discussions and feelings of panic; where would this all lead? Chaos was uncomfortable.

The discomfort this student described is the first step in the transformative learning process. For the three ensuing months, learners are helped to examine the discomfort they may be feeling, as they ask themselves and each other questions such as these: Why are we uncomfortable? What assumptions are we making? How does our behaviour reflect these assumptions? What impact does this have on other individuals, teams, and the learning organization as a whole?

What makes it possible to endure, and even to enjoy, such an experience is that the level of support offered to each learner equals the level of challenge. Participants are helped to acknowledge their strengths and successes; to see obstacles not as failures but as learning opportunities; and to celebrate each step of progress towards their vision. Not only do they consistently receive positive as well as constructive negative feedback from their team and classmates, but they are also taught how to offer such feedback effectively and receive it graciously. The result is insights such as the following.

If I couple reflection with my need for harmony, I can become more patient and tolerant of differences, and be less intent on getting the world to adopt my approach. 
Two members who conflicted early were able to successfully confront some of their assumptions about how "leadership" and "commitment" were defined.

I have come to understand ... that this belief in my own "powerlessness" has had a large impact on my commitment and energy for organization development work.

Mezirow (1975) refers to transformative learning as "perspective transformation." He describes this as a process of experiencing a disorienting dilemma, followed by self-examination, critical assessment, relating to others' experiences, exploring options, building competence, developing a plan of action, acquiring knowledge and skills, making provisional efforts, renegotiating relationships, and reintegration. This description quite accurately outlines the experience of most 1130 participants as they design, facilitate, evaluate, and reflect on their teachinglearning activities, both as individuals and as members of a learning team. The demands of envisioning mutually satisfying goals, setting norms for team behaviour, managing conflicts and differences as they arise, giving and receiving feedback during peer evaluation, and trying to make the best possible use of every member's resources create a potential for team learning that is undoubtedly transformative.

One student said:

My understanding of different aspects of group dynamics expanded ... I've become more aware of how different people's perceptions are, and have become sensitive to the relativity of interpretations and judgements.

Another said:

What happened was real learning-and with this learning came a shift of mind. A shift of mind to see that what was alienating me was not outside my control, but was in fact a series of structures that I had built and maintained for myself. Coming to understand these structures has made all the difference.

\section{Examining Mental Models}

Several design features of course 1130 support the transition from emotional experience to integrated learning. One of these is a series of instructor-facilitated, reflective sessions that alternate with the student- 
directed "learning events." A key component of these classes is the opportunity for each team to reflect on its previous week's event. The reflection is often done in a "fish-bowl" format, where team members talk with one another about their reactions to and perceptions of their own work, while the rest of the class listens in. Later, the dialogue is opened to include all of us, and it usually involves questioning and challenging assumptions, requesting and providing feedback on behaviour, confronting conflictual issues, and generally deepening the learnings from the previous week's work. In this way, the teams are encouraged to debrief their experience publicly, so that every class member has an opportunity to learn from their insights.

All of this is framed by theoretical content on the "learning organization," explored during part of the alternating sessions and offered to the learners by the instructor and guest speakers, or through readings, discussions, and films.

Mezirow's more recent writing on transformative learning, which evolved from his critical theory of adult education, stresses the process of examining perceptions by questioning, validating, and revising our assumptions, or "meaning perspectives" (1991). Many other educational theorists have addressed this notion, generating concepts such as Argyris's "ladder of inference" (1990), Argyris and Schön's "left-hand column" (1974), and Senge's "mental models" (1990). Cranton (1994) notes that unquestioned, unexamined, perhaps even unconscious assumptions limit the learner's openness to change, growth, and personal development. She believes that the role of the transformative educator is to help learners question these assumptions or mental models by developing their reflective judgement through such consciousness-raising activities as: role-playing with skillful debriefing; examining critical incidents; and engaging in simulations and games to help learners view situations from alternative perspectives.

Course 1130 uses many such experiential learning approaches, both within the student-facilitated learning events and the alternating instructorled sessions. An example of one approach is the use of Argyris and Schön's "left-hand column" (1974) to help learners explore how mental models limit us to familiar ways of thinking and acting and allow us, in Argyris's terms, to be "skillfully incompetent" (1990). After an introduction to the concept, the class is asked to reconstruct a dialogue that has actually occurred in one of the sessions-preferably one in which there has been some tension among group members. Once this dialogue is recorded on an overhead 
transparency, members are then asked to offer their honest, unspoken thoughts as the dialogue was occurring, and this is recorded in the "lefthand column" opposite the actual spoken conversation. The level of authenticity and the resulting awareness engendered by this simple exercise are often astonishing in their impact. Figure 1 illustrates one class dialogue that was reproduced using this method.

\section{Left-Hand Column}

Thoughts Behind The Words

STUDENT B: What right did they have to change the location without consulting the rest of us?

STUDENT A: Oh god, she's all upset-let's just forget it if it's going to be this much of a problem.

STUDENT B: I really feel manipulated into being seen as a "spoil-sport" here.

STUDENT A: Geez-you try to do something different, and there's always somebody who has a problem with it.

\section{Right-Hand Column}

What Was Actually Said:

STUDENT A: "We have changed the location of our next class to xxx."

STUDENT B: "I have a problem with that. I need to be at another meeting just before class. I won't have time to get to the new location."

STUDENT A: "We thought it would be nice to have a change of venue, but we don't have to do it."

STUDENT B: "I'm not trying to be uncooperative, but I'm really in a bind."

STUDENT A: "O.K., forget it. We won't go —we didn't mean to upset anyone."

Figure 1: Sample of a Reconstructed Class Dialogue

Once the two learners were willing to "expose" their left-hand-column thinking, the class had a very productive dialogue about group consultation when decisions are being made. The actual problem was resolved by changing the starting time to allow for the extra travel involved in holding the class at the new location, and "Student B" was one of the first to arrive. 
One insight resulting from this exercise was described by "Student B" in her final paper.

The change of venue for Team Two's learning event was, for me, a powerful example of Senge's "mental models" at work. Upon further reflection, I became aware of the influence of my values ... on my thoughts and feelings. My concern about the reaction of the class to my dissatisfaction with the decision-making process limited my ability to disclose my deeper emotional reaction to the situation and to the responses of my classmates.

Students in 1130 practise decreasing the limiting power of their mental models by learning to apply certain skills. Originally described by Argyris and Schön (1978), these skills include: recognizing "leaps of abstraction" that take them from observation to generalization; exposing and articulating what is normally deemed undiscussable (filling in the "lefthand column"); balancing inquiry and advocacy to sustain interpersonal dialogue; and differentiating between "espoused theories" (what we believe) and "theories-in-use" (how we actually act out our beliefs).

\section{Systems Thinking and Personal Mastery}

Although course 1130 represents the "learning organization" as a systemic whole, in the end, it is individual personal mastery that enables the system to flourish. I have juxtaposed systems thinking and personal mastery in this section because they are interdependent opposites-or, in Barry Johnson's terms (1992), "polarities to manage."

On the one hand, systems thinking holds that when placed in the same system, people, however different, tend to produce similar results. That is, the structure is the key variable that influences behaviour over time. On the other hand, personal mastery implies individual responsibility and promotes the notion that we have the power-individually and collectively-to alter the structures we operate within. However, we often don't see the structures that are at play; rather, we see our role in isolation instead of recognizing how it interacts within the larger system. We need to learn how to perceive patterns and processes, rather than moments in time.

In 1990, Mezirow claimed that individual perspective transformation must precede social transformation. Senge's The Fifth Discipline, written in the same year, exhorts us to sustain the tension between the two, identifying this as the essence of personal mastery. 
In course 1130, systems thinking has been our greatest challenge. As the learning teams begin their work, the cohesion within these groups intensifies and becomes the main focus of the participants' individual and collective experience. In the light of this, it is difficult to maintain a "whole organization" perspective. One student grappled with this issue in her final paper.

As the weeks passed and the other teams facilitated their learning events, we did not use members of the first teams as resources on event planning. We also did not use later or earlier teams as sounding boards to prescreen programs and provide helpful design input to specific team events. In class, we did not suggest that team members from earlier teams become coaches for other teams.... Throughout the process, it seemed that we gravitated towards operating from a mental model of the organization as discrete operating units with no interconnection.

Although this may be the case, the opportunities for personal mastery in course 1130 help make possible the foregoing insight. Personal mastery, according to Senge (1990), is the discipline of generating and sustaining creative tension in our lives. From the beginning, students in 1130 are challenged to manage the tension between polarities such as: individual versus group; team versus organization; "gives" versus "gets"; organizational vision versus individual behaviour.

Learners also need to be respectful of a wide range of individual differences among their student colleagues-differences in learning, personality, and cognitive styles; cross-cultural differences; differences in background, age, and developmental stage; a wide range of differences in work experience and interests; and differences in openness to a selfdirected learning opportunity. All of these hold the potential for creative tension, both intra- and interpersonally. The way in which these tensions are managed, and consequently how the transformative process is experienced by learners, varies as much as the individuals themselves. After course 1130, one student reflected:

My awareness of my own self and how I relate to others expanded considerably. I have become more sensitive to other peoples' needs, their perceptions, their issues, their processes, and have started to respect their right to it more than before.

The methods used in course 1130 to encourage individual reflection are not in any way new to the adult educator. They include the time-tested 
vehicle of personal journal keeping, a self-evaluation component for the course grade, and a final reflective paper. In the paper, students are asked to use any theory they have encountered of organization design/ development/learning to analyze their own experience as a member of our "learning organization." They can either examine their experience generally or pursue a particular area of interest that has been provoked by the course experience, and they can also include case examples from their work lives. Many students report that writing the paper is an extremely important step in their reflective process, providing them with an individual opportunity for expression, in contrast to the team efforts required in class sessions.

Finally, the act of living the learning by applying it to "real-life" settings is the bottom line of personal mastery. It is one thing to experiment with new behaviour in a classroom setting; it is quite another to apply the learning with colleagues and supervisors or clients at work, or with family and friends at home. It is in this arena that transformative learning can truly have an impact on social change. An 1130 student wrote the following, three months after the course ended.

I would like to underline a very subtle, yet very transformative, organic and creative nature of this process of continuing to learn and change after the actual learning has happened in real time. There is a richness of insight and new behaviours which came to me later. I wonder how it is possible that all these delayed messages are so deep and meaningful, and how come it is that I wasn't aware of them before. It feels like the real process of discovery started after the course had ended ... Professionally, whole new worlds opened for me, and I actually feel I leaped to a new and unexpected skill level, in what feels like "overnight." This has been confirmed by feedback from people I work with, and the success of my facilitation sessions. This is curious, because I didn't have much explicit knowledge about this area prior to starting your course.

Another student reflected on the impact of his learning in his final paper. Seeing and feeling the power of a learning organization has reminded me of why my work is so worthwhile on a human level, and how it can contribute to transformation in both our work and broader communities ... Specifically, I can contrast the practices of my OISE learning organization with the practices of my home organization. By holding up a working model of my vision against my current reality, I have been able to see opportunities and to discuss them in concrete terms with my partners. 


\section{The Facilitator's Role}

Sometimes I think that so many aspects of our group experience, including your facilitation, all spoken and unspoken dimensions and processes of group dynamics, all the subtleties of design, your incredible attention to detail ... everything mattered so much, though I didn't necessarily perceive it like that at the time. I think especially the power of the facilitator's behaviour is enormous in this setting.

In order to foster personal mastery in organizations, Senge (1990) encourages the building of organizational settings where creating visions is safe, inquiry and commitment to truth are the norm, challenging the "status quo" is expected, and leaders at all levels model the behaviour. This last point, the importance of organizational leaders "walking their talk," is emphasized consistently in leadership research (Block, 1987; Kouzes \& Posner, 1991; Wheatley, 1992). The implications for the instructor in a course such as 1130 are apparent and must be included in a discussion on transformative learning.

Earlier in this paper, a distinction is made between three approaches to adult learning: subject-oriented, consumer-oriented, and transformative or emancipatory learning. Cranton (1994) notes that the power attributed to the educator's role differentiates these perspectives, with the power of the educator progressively decreasing as one moves from subject- to consumerto transformative-oriented roles. The notion here is that the more one works towards learner empowerment, the more likely that critical self-reflection and transformative learning will occur. Increased freedom and autonomy are both prerequisites for and anticipated outcomes of this process.

Of course, such challenges to the authoritarian "status quo" of our culture are not always easily met by even the most mature learners. One 1130 student astutely reflected on this issue.

During the class I saw the participants, myself included, looking to the facilitator for guidance and direction, even though care was taken to give the group choices in how things were done, what topics were covered and the pacing of material. We were again influenced by our mental models of an academic organization; the teacher knows the answers and where we should go from here.

We were trying to live Senge's "shifting the burden to the intervenor" archetype (Senge, 1990). The facilitator did not allow us to do this. We 
were asked to make choices about our program content and flow. At times, having twenty people involved in a decision seemed unwieldy, especially since the mental model we were working from seemed to give power only to the facilitator. The quick fix would have been to have the facilitator make the choices. The systemic solution took longer to achieve, and, in the longer term, will provide a more meaningful solution for all of us. Learning to set our own direction was important on two fronts. As individual learners we need to know where we want to go, and as members of organizations we need to understand how to help others set their own direction.

In order to accomplish this process of empowerment, the educator's role changes from that of facilitator in creating a productive working environment, to that of co-learner as students participate in discourse and decision making, to that of provocateur to help learners think critically. The educator also assumes the role of counsellor, friend, and supporter to help people through what might be painful processes of change and, finally, the role of resource person to help learners plan actions based on their revised assumptions (Cranton, 1994). In a classroom setting, the educator's efforts towards learner empowerment may include sharing control over resources, rewards, information, and the environment by inviting progressively more participation in decision making in all of these areas as the course unfolds.

In a graduate course such as 1130, informal, as well as formal, feedback and evaluation/grading are the key extrinsic "rewards" available to learners. The 1130 course information outline specifies from the start that grades will result from a combination of individual, team, whole group, and instructor evaluations.

Specifically, 25 percent of every student's grade is based on his or her own team's assessment of its success as a learning unit, supported by feedback from the rest of the learning organization members. This assessment is designed by team members, based on their own goals and vision, and involves making decisions such as: what criteria to use; whether to assign a team grade or grade every member individually; whether to provide feedback openly or anonymously; and whether or not to include a self-assessment component.

Another 25 percent of the grade is decided by members of the class as a total group, based on the goals and vision developed over the term and on how well the group has progressed towards these in functioning as a learning organization. Again, the process is designed by the group as a whole, with little if any content input from the instructor. 
The remaining 50 percent is assigned by the instructor, based on a final written paper submitted by each student, as previously outlined. In this way, participants and instructor are equally responsible for each learner's final grade.

A second area in which control of resources is shared by the group is the allocation of the course's $\$ 1,000$ budget. This money is taken directly from program fees and returned to the students as a resource to use for the purchase of relevant articles, books, or other materials, film rental fees, honoraria for guest speakers, or any other expense the group might encounter over the thirteen-week term. The allocation of this budget is entirely in the hands of the participants, and decisions regarding its use are usually an important focus of the group's planning activities.

Finally, the content of the course is essentially decided by the class members. Although I provide a skeletal theoretical framework using basic learning organization principles, each year's student group "fleshes out" this framework to include specific content interests. Each teaching-learning event is focused on a content area of interest to the group as a whole, and the alternating week's reflective sessions are guided by issues that have surfaced during these events. The planning involved in all of this activity constitutes an important part of the learning experienced by each member of the developing organization.

References and reading materials to support this learning are initially provided by the instructor, but eventually all class members share this role as well. During the fifteen minutes allocated each week to resource sharing, learners inform each other about upcoming conferences and other professional development opportunities and recommend articles, books, films, and speakers, as well as offering myriads of other relevant data. The classroom itself begins to resemble a library, stocked each week with journal articles and books provided by all members of the group. Finally, each participant provides several entries to a class annotated bibliography, with brief comments on favourite books and articles, which are then compiled and distributed to everyone for further reference.

Although sharing control in this manner appears to be a critical component of facilitating transformative learning, the final word on the facilitator's role needs to address the issue of personal authenticity. The key challenge for me as the instructor/facilitator in a course of this kind is to ensure that my behaviour is unerringly consistent with the principles being taught and learned. This implies being willing to share my vulnerabilities and doubts, remaining open to being critiqued and to questioning my own 
thinking, and eliminating my investment in "being right." Well beyond the design and facilitation of course 1130, such personal challenges have been my learning edge. The opportunity presented to me in teaching this course is to continually hone my ability to be a reflective practitioner. Critical reflection is not something that is learned theoretically. In the end, I believe that the act of consistently making explicit one's assumptions and beliefs is the key to both promoting and experiencing transformative learning, for instructors and students alike.

\section{CONCLUSION}

The purpose of this paper has been to examine the nature of experiential education in the light of transformative learning theory, using a graduate course as a case example. Through an analysis of the design and implementation of course 1130, the paper attempts to provide specific ideas for how graduate education can contribute to significant personal change in the values, attitudes, and behaviour of adult learners.

Is the course described in this paper truly transformative? This is difficult to judge conclusively given the fact that many participants only begin to recognize the learning they have experienced once the course is over. However, if transformation means "a change in form or disposition," as my 1989 Webster's dictionary defines it (p. 232), then the following statement from an 1130 student would lead one to believe that transformative learning is indeed a result, at least for some learners in course 1130 .

... I am discovering new layers every day ... and I am taken aback by the richness and the sheer scope of new learnings. I felt differently right after the course. Although I felt I learned a lot about the process and design, and about the learning organization, I didn't feel personally affected by that knowledge. And then, after about a month or so, after I interacted enough with the outside world to notice changes, I started feeling that I was influenced and changed far more than I expected. The mental and emotional images from the time of the course became more vivid and more often present in my mind. They were coming back to me forcefully and gently at the same time, and staying with me. I was getting new insights for the first time, and was able to see some things in a totally different light.... Perhaps because my experience in the course was so rounded and full, and touched every aspect of my being, the actual transformation has been occurring. 


\section{ACKNOWLEDGEMENT}

I gratefully acknowledge the following graduate students whose course evaluations, final papers, and written correspondence provided me with the anecdotal data for this article, and who, along with their colleagues, have made teaching course 1130 one of the most satisfying experiences of my career.

Doug Berquist (1994)

Marina Glogovac (1995)

Loren Grebanier (1993)

Bernie Korte (1995)

Heather Ramsey (1992)

Shannon Reilly (1995)

Stephen Scanlan (1992)

Suzanne Wolfe (1995)

I would also like to express my appreciation to Dr. Gwenna Moss, Editor of the Canadian Journal of University Continuing Education, and three anonymous reviewers for their thoughtful feedback in the writing of this article.

\section{REFERENCES}

Argyris, C. (1990). Overcoming organizational defences: Facilitating organizational learning. Needham Heights, MA: Allyn \& Bacon.

Argyris, C., \& Schön, D. (1974). Theory in practice: Increasing professional effectiveness. San Francisco: Jossey-Bass.

Argyris, C., \& Schön, D. (1978). Organizational learning: A theory of action perspective. Reading, MA: Addison-Wesley.

Block, P. (1987). The empowered manager: Positive political skills at work. San Francisco: Jossey-Bass.

Brookfield, S. (1987). Developing critical thinkers: Challenging adults to explore alternate ways of thinking and acting. San Francisco: Jossey-Bass.

Cranton, P. (1994). Understanding and promoting transformative learning. San Francisco: Jossey-Bass. 
Cross, P. (1992). Adults as learners: Increasing participation and facilitating learning. San Francisco: Jossey-Bass.

Field, L., \& Ford, B. (1995). Managing organizational learning: From rhetoric to reality. Melbourne, Aus.: Longman House.

Galbraith, M.W. (Ed.). (1990). Adult learning methods: A guide for effective instruction. Malabar, FL: R.E. Krieger.

Jarvis, P. (1992). Paradoxes of learning: On becoming an individual in society. San Francisco: Jossey-Bass.

Johnson, B. (1992). Polarity management: Identifying and managing unsolveable problems. Amherst, MA: HRD Press, Inc.

Knowles, M. (1984). The adult learner: A neglected species (Rev. ed.). Houston: Gulf.

Kouzes, J., \& Posner, B. (1991). The leadership challenge: How to get extraordinary things done in organizations. San Francisco: Jossey-Bass.

Mezirow, J. (1975). Education for perspective transformation: Women's reentry programs in community colleges. New York: Columbia University, Teachers College, Centre for Adult Education.

Mezirow, J. (1981). A critical theory of adult learning and education. Adult Education, 32, 3-24.

Mezirow, J. (1991). Transformative dimensions of adult learning. San Francisco: Jossey-Bass.

Mezirow, J., \& Associates. (1990). Fostering critical reflection in adulthood. San Francisco: Jossey-Bass.

Patterson, R. (Ed.). (1989). New Webster's dictionary. Florida: PSI \& Associates, Inc.

Senge, P. (1990). The fifth discipline: The art and practice of the learning organization. New York: Doubleday Currency.

Wheatley, M. (1992). Leadership and the new science: Learning about organization from an orderly universe. San Francisco: Berrett-Koehler Publishers, Inc. 


\section{BIOGRAPHY}

Marilyn Laiken is an Assistant Professor of Adult Education and the Coordinator of the Workplace Learning and Change Focus at The Ontario Institute for Studies in Education of the University of Toronto. She is also President of Laiken Associates, a Toronto consulting firm, which has served over one hundred clients in the public, private, and not-for-profit sectors.

Marilyn Laiken est professeur adjoint en éducation aux adultes ainsi que coordonnatrice de Workplace Learning and Change Focus à l'Institut d'études pédagogiques de l'Ontario à The University of Toronto. Elle est aussi présidente de Laiken Associates, une entreprise d'experts-conseils, ayant servi plus de cent clients dans les secteurs publique, privé et sans but lucratif. 